\title{
UK BASED MICROSURGICAL TRAINING
}

\author{
1 Broadsands Gardens, Dartmouth Rd, Brixham, Devon TQ5 OFG, UK
}

This describes the UK history of the evolution of microsurgical training. The author has been involved since the start in 1979 and took a sole teaching role in the courses 2 years later. Before teaching microsurgery the necessary skills were obtained by the performance of various organ transplants in mice, rats and rabbits to investigate organ storage and immunosuppression. This experience identified the pitfalls of microsurgery and amplified the then identified need for meticulous microsurgical training. A basic microsurgical program was then instigated to provide step by step exercises of increasing difficulty. This consisted of microscope set-up, correct positioning, instruments, simulated suture exercises, dissection techniques, end to end arterial and venous anastomosis, end to side anastomosis, interpositional vein grafts, nerve anastomosis and groin flaps - all performed on an anaesthetised rat. Latterly we are now running advanced workshops incorporating supramicrosurgical exercises in the chicken (thigh) and the rat. The microsurgical workshops are still running 41 years later!

Keywords: microsurgery, microsurgical training, Simulation assessment.

Conflict of interest: the authors declare the absence of obvious and potential conflicts of interest related to the publication of this paper.

Financial disclosure: no author has a financial or property interest in any material or method metioned.

For citation: Shurey S. UK based microsurgical training. Issues of Reconstructive and Plastic Surgery. 2021;24(1):48-55. doi: 10.52581/1814-1471/76/5

\section{ОБУЧЕНИЕ МИКРОХИРУРГИИ В СОЕДИНЕННОМ КОРОЛЕВСТВЕ (ВЕЛИКОБРИТАНИИ)}

\section{С. Шури}

\section{Broadsands Gardens, Dartmouth Rd, Brixham, Devon TQ5 OFG, Beликобритания}

\begin{abstract}
Представлена история развития обучения микрохирургии в Великобритании, в котором автор принимала участие с момента старта программы в 1979 г., а 2 года спустя стала единственным преподавателем на курсах. Перед началом преподавания микрохирургии она получияа необходимые навыки при выполнении различных транспиантаций органов у мышей, крыс и кроликов Аля исследования органов и иммуносупрессии. Этот опыт выявил поАводные камни в микрохирургии и усилил появившуюся тогАа потребность в тщательной микрохирургической подготовке. Затем была разработана базовая микрохирургическая программа, в которой преАлагались пошаговые упражнения возрастающей сложности, которые включали установку микроскопа, выбор правильного позиционирования, выбор инструментов, имитацию наложения швов, технику рассечения, арте-

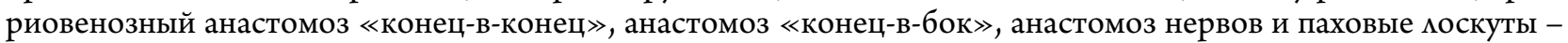
все эти процеАуры выполнялись на анестезированных крысах. В последнее время мы проводим расширенные семинары, включающие супрамикрохирургические упражнения на курицах (беАро) и крысах. Спустя 41 гоА после старта обучения микрохирургические семинары по-прежнему успешно работают.
\end{abstract}

Ключевые слова:

Конфмикт интересов:

Прозрачность финансовой Аеятельности:

Амя цитирования: микрохирургия, микрохирургическое обучение, симулиионная оценка.

автор подтвержАает отсутствие конфмикта интересов, о котором необходимо сообщить.

автор не имеет финансовой заинтересованности в преАставленных материалах или методах.

Шури С. Обучение микрохирургии в Соединенном Королевстве (Великобритании). Вопросы реконструктивной и пластической хирургии. 2021;24(1):48-55. doi: 10.52581/1814-1471/76/5 


\section{HISTORY}

The first microsurgical course in the UK was setup in 1979 at Northwick Park Hospital, London, some three years after Alain Gilberts' Paris based course.

The need for training was instigated by Prof Colin Green ( Medical Research Council (MRC)) who was using microsurgical techniques in his experimental rabbit renal transplantation and by three young like-minded plastic surgeons - Michael Black, Gus McGrowther and Roy Saunders (all now Professors!).

They realised that with the advent of clinical free flaps the microsurgical aspect could not be acquired without some sort of formal training.

I started work for the Medical Research Council (MRC) in 1976 and by 1979 was involved in running the microsurgical workshops having honed my skills on organ transplantation in small animals.

About a year or so later the microsurgical course at Canniesburn, Glasgow, Scotland also started, run by the plastic surgeons working there and to date is still taking place.

\section{TRAINING PROGRAM}

The initial course lasted three days and utilised rabbits. It was soon apparent that these were not ideal subjects for training due to anaesthetising en-masse and so the rat was subsequently chosen.

Twelve trainees attended the three day course. Most were plastic surgeons with a few orthopaedics. At that time Zeiss kindly lent us the microscopes (we purchased them in 1986) as the cost in those days for purchasing new machines was exorbitant. Instruments and clamps were expensive but were purchased new from $S \& T$.

Initially topics covered were the microscope set up, femoral vessel dissection and end to end and end to side anastomoses. Lectures on freeflaps were also included. After the first few courses it became apparent that the surgeons were just getting into their stride by day three and that they wanted more hands on time rather than the lectures. From then on the lectures were dropped and the course extended to five days. This meant we could now incorporate vein grafts, nerve anastomosis and a groin flap based on a $0.5 \mathrm{~mm}$ epigastric artery and $1 \mathrm{~mm}$ vein (now termed supra microsurgery!).

We ran one weekly course per year. As demand soared, by the mid-eighties we were running ten courses a year for up to seventeen participants with a ratio of one lead tutor (Mrs Sandra Shurey) and two trained technicians. By the mid-nineties plastic surgeons were nearly outnumbered by the influx of maxillofacial surgeons and this balance has remained to date. We also had the odd cardiac, vascular, urologist and hand surgeons from the Nordics.

In 1986 we also produced an in house manual of 'Basic Microsurgical Techniques' that we supplied to all our training surgeons and this was updated in 2010. Colin Green also published an article on microsurgical training (1. Green, 1987).

In 1994 the MRC was dissolved and under Prof Green the courses continued under the umbrella of the Northwick Park Institute for Medical Research NPIMR). From 2019 NPIMR was rebranded as the Griffin Institute.

Around 2012 we also included a five day advanced course that incorporated advanced dissection skills, working at depth, continuous suturing, suturing the posterior wall through the anterior and more microsurgery at supra microsurgical levels both end to end and end to side.

Basic and advanced courses are currently being run at the Griffin Institute (2020).

Due to retirement I have set up a unique home based microsurgical training, running the basic training on a chicken model. For low cost the surgeons can attend a one day refresher or attend a complete five day course. This has proved a popular choice. Information on the UK home based training can be found on my Facebook page (2. Shurey, 2020. MicroShure Microsurgery).

For both Basic and Advanced courses we promoted a step by step learning model with exercises increasing in difficulty as the course progressed.

\section{STEP BY STEP GUIDE TO AN END TO END ARTERIAL ANASTOMOSIS}

(5. Shurey, 2020. Module 6: End to End Arterial Anastomosis).

The routine described here is for the Acland vessel approximating clamp (ABB-1), but this can be adapted to other types of double clamp on a slide bar.

The main point of having the two clips on a bar is to allow them to slide toward each other and thus ensure that the divided ends of the vessel are brought close together and are under no tension whatsoever whilst being anastomosed.

Having rinsed the ABB-1 in heparinised saline, it is placed it in the operating field and viewed under low magnification the two clips are slid as far apart on the bar as possible. The clamp is placed over the background material and under the artery until just the clip tips project slightly beyond the vessel with the artery lying in a straight line over the two clips. 


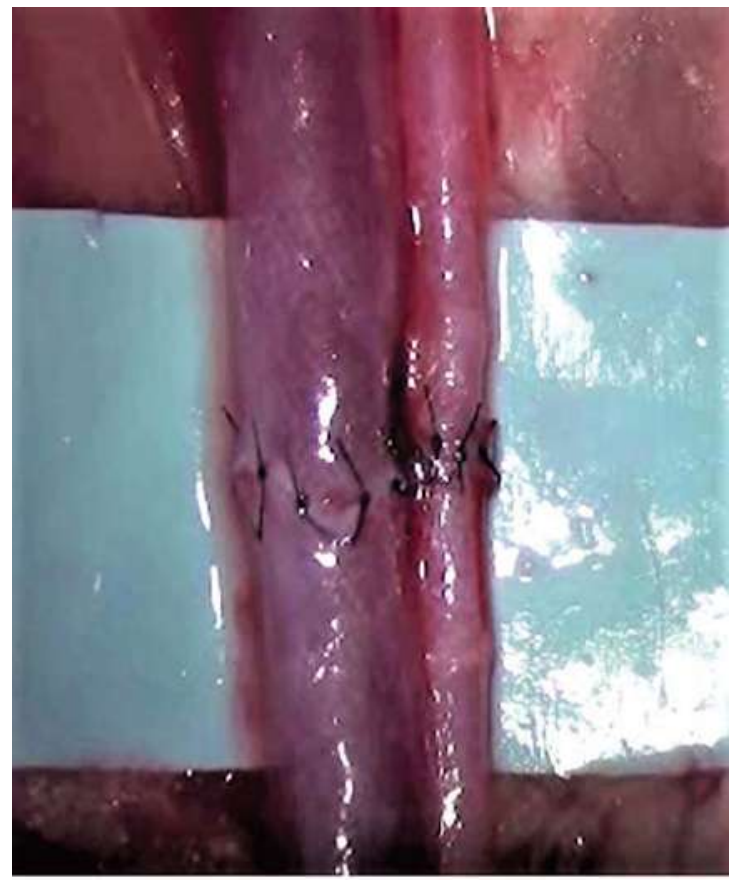

Fig. 1. End to end anastomosis of rat femoral artery and vein

Рис. 1. Анастомоз «конец-в-конец» беАренной артерии и вены крысы

With the clamp appliers, the proximal clip is opened, the artery grasped by its adventitia and pulled longitudinally into the open clip before closing. The distal clip is opened and the artery pulled longitudinally toward the centre of the frame, it is slid into the clip and the clamp closed.

This manoeuvre ensures a relaxed length of artery between each clip. Do not twist the vessel and ensure that it is held at the tip of the clip, clamping the vessel nearer the clamp bar will lead to vessel slippage when the clamp is pivoted.

With the scissors at a right angle to the vessel wall, the artery should be transected halfway between the two clips with one decisive but controlled movement to achieve a clean cut through the full thickness of the vessel. The divided ends will retract immediately.

Irrigate the vessel with heparinised saline using a 30 gauge Rycroft air cannula attached to a $1 \mathrm{ml}$ syringe.

The clips are now slid gently toward each other until the retracted vessel ends are close together. If ample arterial length has been included between the clamps then they will only need to be pushed together a little, thus leaving plenty of room to do the anastomosis without the clips getting in the way when the needle is being passed.

The chicken artery is non-viable so will not retract once transected so just apply clamps without pulling excess artery between the clamps.

The femoral triangle should now be thoroughly irrigated until it is full of fluid and the divided ends of vessel are floating freely. Only then is it possible to see the loose adventitial tissue. It is important to remove this for $1-2 \mathrm{~mm}$ from the anastomosis edge.

The simplest method of doing this is to grasp the tissue with No. D-5a forceps, pull it gently over the vessel-end until a cone or sleeve is formed. Amputate it cleanly in one snip at the level of the underlying stump, the remaining tissue will retract back, leaving the vessel with a clean end.

The chicken artery has very little adventitia so do not overstrip.

Interrupted sutures of 10/0 monofilament polyamide or monofilament polypropylene are used on the rat femoral vessels $(8 / 0$ or $9 / 0$ can be used for the chicken artery). The simplest technique is to join these vessels end-to-end using the triangulation method.

The idea of this is to place the first two stay sutures at $120^{\circ}$ and then apply horizontal tension. This flattens and stabilises the anterior wall whilst the posterior $240^{\circ}$ falls away from the anterior. This helps to prevent catching the posterior wall when suturing the anterior and makes the anastomosis much easier to perform.

If the first two stay sutures are inserted at $180^{\circ}$ and tension applied the two vessel walls 'sandwich' and the posterior wall could easily be caught in the anterior stitch.

The first stay suture is placed at 2 o'clock around the circumference and secured to the furthest cleat.

The second stay suture is placed on the opposite side of the front wall $120^{\circ}$ apart and secured to the other cleat with sufficient traction to stretch the anastomosis line laterally.

The front wall is now sutured using square or reef knots which must lie flat against the anastomosis line.

Under no circumstances must 'granny' knots be made as the ends can easily project through the suture line and into the lumen. Each suture must penetrate the full thickness of the vessel wall and the bite should be about $1.5 \mathrm{x}$ the vessel wall thickness.

For intermediate sutures it is easier to pass the needle through both sides of the anastomosis in one movement without releasing the holder.

One suture is placed (the holding suture) equidistant between the two stay sutures and the proximal end left long so that it can be grasped with forceps to raise and stabilise the vessel walls whilst intermediate sutures are placed.

The clamp is turned over before tying this suture taking great care that the cleats do not snag or puncture the adjacent vein, and make sure that the back wall has not been picked up. If all is well, return the clamp back again and complete the stitch. 
The next suture is placed near the first stay suture, and thereafter they are placed at intervals approximately one needle diameter apart working toward the middle holding stitch.

The other quadrant of the front wall is completed in the same way.

The long uncut end of the middle suture has been used to hold the anastomosis for each of these sutures thus avoiding all handling of the media or intima, and this technique is simpler than picking up the adventitia with forceps.

Having completed the anterior wall, the area is irrigated and the approximating clamp turned $180^{\circ}$ so the arterial posterior wall is revealed. The lumen is irrigated with heparinised saline.

If it is necessary nudge each clamp a little closer together to ensure that the suture line is not under tension.

Place the first (holding) suture equidistant between the two stay sutures and, after tying a square knot, leave the proximal end uncut so that this can be grasped to pull the posterior wall away from the anterior and stabilise it whilst the needle is passed for the intermediate sutures.

Remember throughout to use high magnification $(10 x)$ to place the sutures and low magnification $(4 \times)$ whilst tying.

Depending on the size of vessel use $\sim 10$ sutures for the complete anastomosis.

After irrigating the field, the clamp is now rotated back to its original position and the artery checked to ensure that it is not adhered to the metal frame.

The stay sutures are divided close to the knots. The distal clip is opened first and the vessel slid out of the clip. Blood should immediately fill the vessel back to the proximal clip having crossed the suture line. Once the anastomosis has stopped oozing, the proximal clip is opened and the artery slid out. Under low magnification, gentle pressure is applied over the suture line with microsurgical swabs until any oozing has stopped.

Pulsatile bleeding must be considered a surgical failure and another suture should be placed after re-clamping and irrigating.

In some clinical circumstances it is not possible to use a double approximating clamp in which case single clamps may be used and the stay sutures attached to the single clamps to hold the stay stitches under tension.

It may also be impossible to use the triangulation technique because vessels cannot be turned over easily (due to lack of access or tension) so it may be necessary to suture the posterior wall first with one suture then gradually work round to the anterior until the anastomosis is completed.

\section{STEP BY STEP GUIDE TO AN END TO SIDE ANASTOMOSIS (RAT FEMORAL ARTERY TO FEMORAL VEIN)}

(6. Shurey, 2020. Module 8: End to Side Anastomosis).

In the rat and the chicken the most convenient and simplest model for end-to-side anastomosis is to attach the end of the artery to the side of the vein.

Both vessels are prepared with the backing material placed under both vessels and a few drops of $2 \%$ procaine applied to prevent spasm.

In the rat, using a single Acland clamp, the artery is occluded as near to the inguinal ligament as possible and the distal end of the artery ligated at the junction with the superficial epigastric origin. The artery is transected straight across close to the tie and adventitial tissue removed by the sleeve technique.

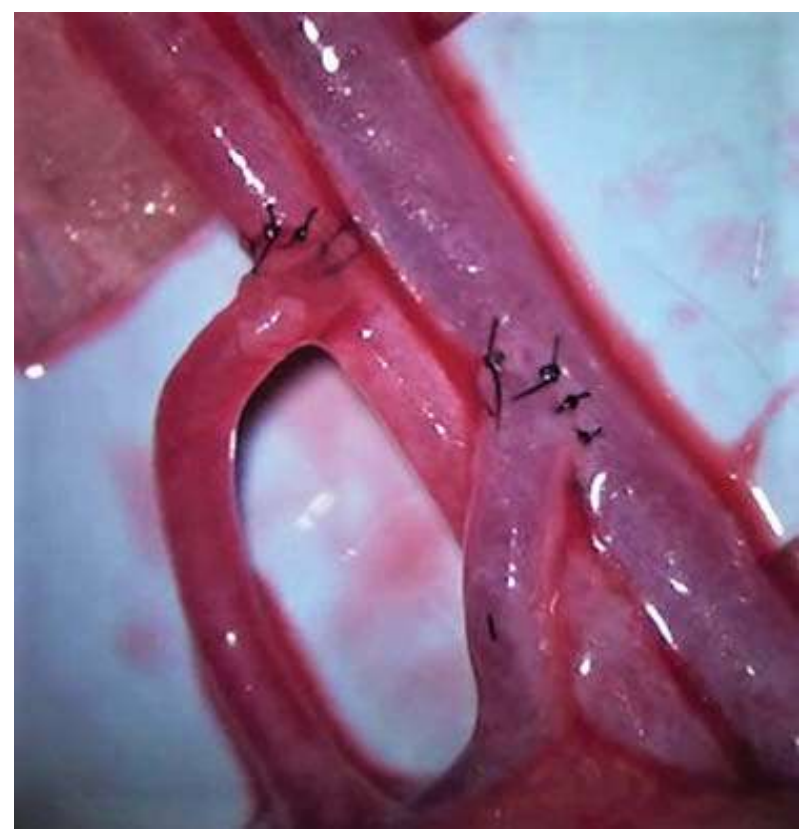

Fig. 2. End to side anastomosis of rat epigastric artery and vein to the femoral artery and vein

Рис. 2. Анастомоз «конец-в-бок» эпигастрамьной артерии и вены крысы с беАренной артерией и веной

The chicken artery does not have a 'sleeve' of adventitia so any obvious adventitial tags are trimmed.

The approximating clamp is then positioned under the femoral vein as close to the inguinal ligament as practicable; it is important to clamp the vein here so that the anastomosis can be performed proximal to the point where the femoral artery has been divided so that no tension is placed on the anastomotic site.

With each clip placed as far apart as possible on the approximating clamp, the vein is slid into 
the proximal clip first and the distal clip next as this ensures a ballooned vein. This prevents possible damage to the opposite wall when the venotomy is created. The clips of the approximating clamp are slid toward each other to release any tension. The end of the prepared artery is brought alongside the vein so that the artery lies in a gentle curve without tension.

The venotomy is created on the anterior venous wall and is size matched to the outside diameter of the artery and flushed with heparinised saline. The end of the artery is placed alongside the venotomy ready for suturing. For each suture, take normal sized bites out of both artery and vein, avoiding larger bites on the venous side which can cause constriction. Space the sutures as close together as you would in an artery-to-artery anastomosis (one needle thickness apart).

The first suture is placed at the proximal end of the venotomy passing the needle from the outside of the vein to the inside thence from inside the artery to the outside. The suture is pulled through until the edges of the vessels just meet and a surgeon's knot made leaving one end long enough to attach to the furthest cleat of the clamp, but not to be attached at this stage.

Place the second suture at the opposite end of the venotomy, this time passing the needle outside of the artery to inside thence inside the vein to outside. Place the third suture in the centre of the anterior wall.

Two additional sutures are placed in the front wall, one in each segment between stay and holding suture. Remember to check each intermediate stitch before tying as it is very easy to catch through to the posterior wall. To expose the other side, the long end of the first stay suture is passed under and around the back of the artery. This is used to retract the artery and expose the back wall for anastomosis and is attached to the cleat farthest from the anastomosis.

Take care not to apply to much tension as this can force the arterial and venous wall to lie too close to one another. This stitch is just used to hold the loop of artery gently out of the way.

The back wall is completed in identical fashion to the front. Trim all long ends of knots and cut the stay sutures. Check that there are no obvious gaps when inspected at high magnification and place extra sutures if the gaps look too large.

After each stitch placement gently raise the suture ends before tying to check that the anterior wall has not caught. Additionally keep the vein filled with saline and this too will prevent anterior wall adherence.

Remove the approximating clamp from the vein, proximal clip first, followed by the distal clip. Inspect the posterior wall of the vein to ensure that there are no stitches that have caught through and then remove the single arterial clamp.

Check patency with the milk test.

If the anastomosis is patent, bright red blood should be observed mixing turbulently with venous blood. If the anastomosis is oozing, put gentle pressure over it with a damp swab for a few minutes before re-examining it under magnification. Finally instil a few drops of $2 \%$ procaine around the vessels to prevent or reverse any constriction.

\section{NON-LIVING AND LIVING MODELS USED FOR MICROSURGICAL EDUCATION}

(7. Shurey, 2020. Module 4: Microsurgical Training Models).

\section{Simulated}

Our first exercises are carried out on simulated tissues such as rubber gloves and silicon tubes. The favoured choice for beginners is a glove stapled to card within an envelope, this material is stretchy and more akin to a simulated vessel. The card can also be turned over for stitch inspection. Four $1 \mathrm{~cm}$ incisions (horizontal, vertical and two obliques) are made with scissors and the incisions stitched with 8/0.

Penrose Drain Tubing is a rubber tube ideally suited for simulated anastomosis, it is available in varying widths, the $35 \mathrm{~mm}$ is ideal to start with. Use $6 / 0$ for this as the tubing is quite thick. It can be secured to a cork board with mapping pins in lieu of clamps.

Silastic tubing is soft and easily takes a suture. It is available in many different widths and is suitable for the novice microsurgeon (use 8/0/ \& 10/0).

The finest tubes are suitable for practicing at supra microsurgery levels $(10 / 0$ \& $11 / 0)$.

The PVC Rat is a plastic model of a rat in a supine position with exposed major abdominal vessels and organs

This model allows students to practice microsurgical technique before using live animals, an expensive investment but can be re-used many times.

\section{Biological}

Japanese noodles are very fine and fragile but good models for practicing supra microsurgery $(11 / 0)$. Some students like to use earthworms as they have a more 'vascular' like structure for practice $(8 / 0)$. Also umbilical cords offer long lengths of arteries and veins (8/0, 9/0 \& 10/0). Cryopreserved rat aortas are also excellent models (use 10/0). Pig or Lambs Heart coronary arteries can be freed and anastomosed (9/0) and Pig or Lambs spleen offers a myriad of vessels for anastomosis $(9 / 0$.) 
The best non-living model is the chicken thigh and chicken wing (10/0). This involves some macro and micro dissection of the vessels and nerve $(8 / 0 \& 10 / 0)$ and can also be used to practice supra microsurgical techniques $(11 / 0)$.

The ultimate practice model is the living rat as it provides immediate feedback on the quality of the vessel preparation and anastomoses,

\section{ASSESSMENTS TOOLS FOR MICROSURGICAL TRAINING}

(8. Shurey, 2020. Module 5: Factors Affecting Anastomotic Success).

All participants in our courses were given a certificate of attendance outlining the techniques they had practiced.

Today, the drive is towards the participants being assessed on their performance. There are various scoring mechanisms in the literature describing methods for assessing micro anastomosis but practically they are too detailed to implement in a training environment.

We are currently implementing assessment based on a self- assessment protocol from ( 9 . Ghanem et al, 2016) for end to end anastomosis and for end to side (10. Pafitanis et al, 2017). This was chosen as expert tutor assessment in a microsurgical course can take excessive time and self- assessment over 5 days was proved to be as valid.

They have proved that self-evaluation of an anastomosis using the assessment of skill levels can be compared to that of an experts assessment, each student assesses each anastomotic error and as experience is gained the amount of errors recorded is shown to be reduced.

These two papers contain all the relevant evaluation parameters.

(9. Ghanem A.M. et al. Anastomosis Lapse Index (ALI): A Validated End Product Assessment Tool for Simulation Microsurgery Training).

(10. Pafitanis G., Veljanoski D., Ghanem A.M., Myers S. Intimal Surface Suture Line (EndProduct) Assessment of End-to-Side Microvascular Anastomosis).

\section{MODELS AND TECHNIQUES FOR SUPRAMICROSURGERY}

Supramicrosurgical exercises can be completed in both the chicken and the rat models.

\section{Rat groin flap}

For the purpose of this exercise the groin flap is detached and then anastomosed at the same site to negate the need for any further dissection.
A rectangular area $4 \mathrm{~cm} \times 2 \mathrm{~cm}$ is marked out on the depilated skin. An incision using a scalpel is made around the whole flap. The flap is lifted with micro-toothed forceps at the anterior medial corner and then raised, together with its vessel bearing fat pad, by blunt dissection with round-tipped bow scissors.

Great care must be taken when cutting through the inguinal fat pad at the posterior border of the flap as it usually contains vessel branches. These vessels can be contained within the flap if a larger ratio of fat to skin is taken in this area.

It is important that the whole of the flap is freed from any adherent tissue and that it is completely isolated on the superficial epigastric pedicle. If the flap remains attached by any peripheral vessels during the vascular anastomosis it will become congested and fail.

The epigastric vessels (artery $\sim 0.5 \mathrm{~mm}$ and vein $\sim 1 \mathrm{~mm}$ ) can be used for practicing end to end and end to side anastomoses at supramicrosurgical levels.

(11. Shurey, 2020. Module 10: $<1 \mathrm{~mm}$ End to End Anastomosis).

(12. Shurey, 2020. Module 11: $<1 \mathrm{~mm}$ End to Side Anastomosis).

Other models in the rat can include: Interpositional vein graft $<1 \mathrm{~mm}$ (Fig. 3) and Femoral Artery to Carotid Loop (Fig. 4).

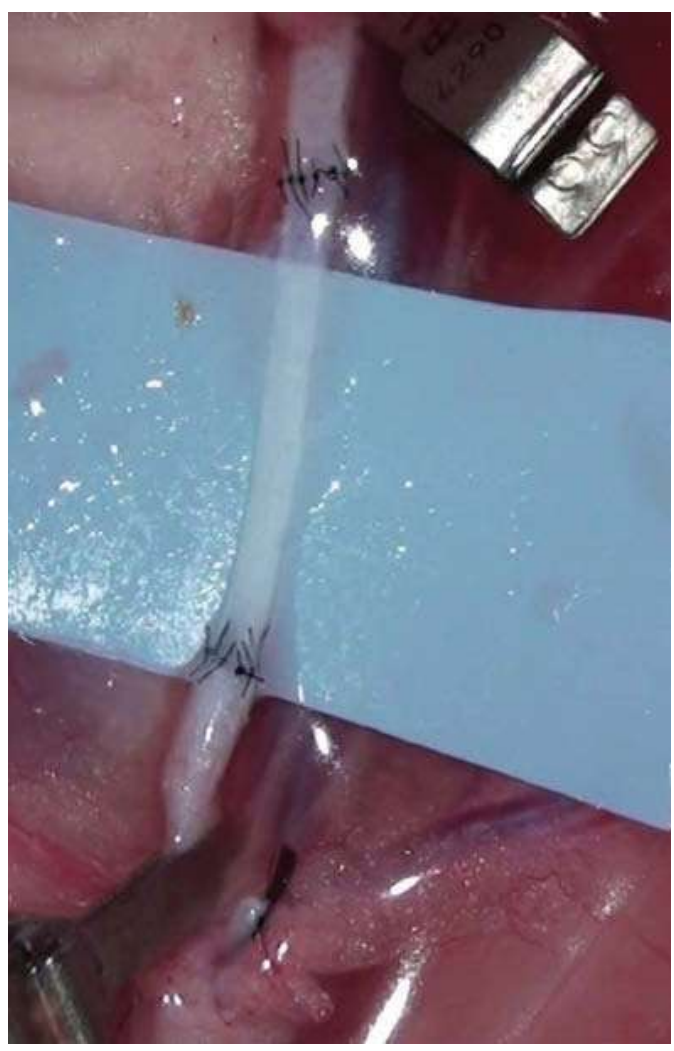

Fig. 3. Interpositional vein graft $<1 \mathrm{~mm}$

Рис. 3. Межпозиционный венозный трансплантат <1 мм 


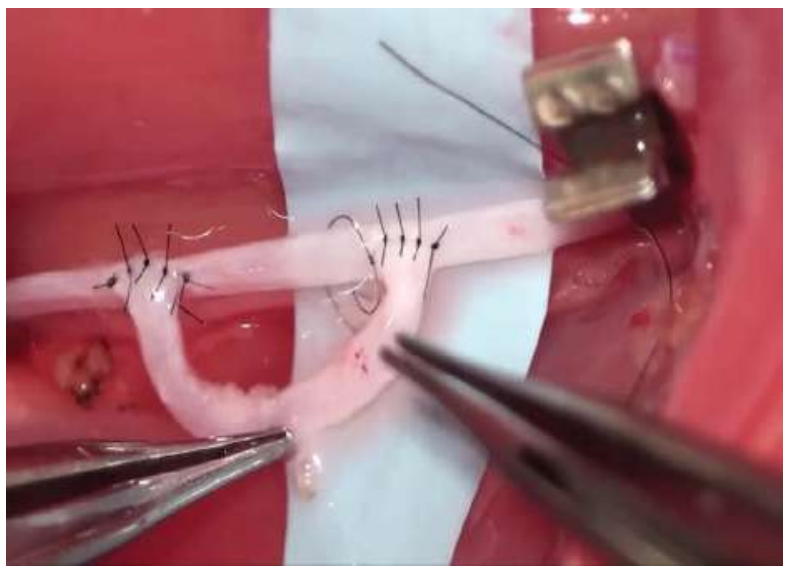

Fig. 4. Femoral artery to carotid loop

Рис. 4. БеАренная артерия к петле сонной артерии

(14. Shurey, 2020. Module 11: Femoral Artery to Carotid Loop).

(15. Shurey, 2020. Module 9a: Interpositional Vein Graft).

To test supramicrosurgical dissection skills the rat renal model can be utilised (Fig. 5).

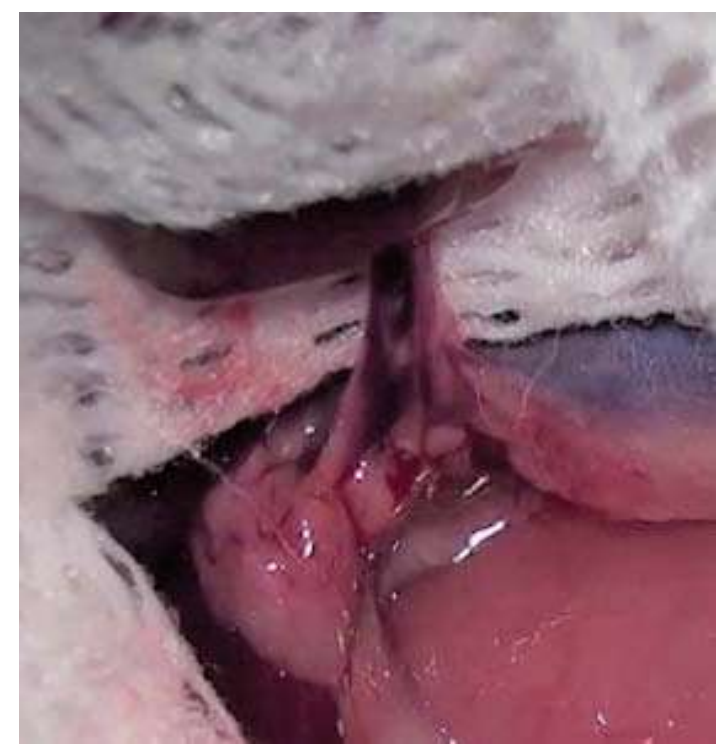

Fig. 5. Renal Vessel Dissection

Рис. 5. Расслоение почечных сосудов

(16. Shurey, 2020. Module 15: Renal Model with Continuous Suturing)

The chicken tributary vessels can also be used for supramicrosurgical exercises such as $<1 \mathrm{~mm}$ end to end and end to side anastomosis as well as the interpositional vein graft.

\section{Chicken}

For dissection practice the chicken vessels can be raised attached to a flap or alternatively the tributary vessels can just be dissected free, cut and anastomosed.

For details of the chicken flap model see:

(13. Pafitanis G. et al., 2017. The Chicken Thigh Adductor Profundus Free Muscle Flap: A Novel Validated Non-Living Microsurgery Simulation Training Model).

Many of these smaller vessels are very fragile and the smaller veins in particular are good models for mimicking lymphatic anastomoses. The main difference with supramicrosurgical anastomoses is the vessel handling. This must be kept to an absolute minimum and the copious use of fluid helps to 'float' the vessels and the weight of the fluid within the vessel lumen helps to keep the lumen open ready for suturing.

\section{Robotic Microsurgery}

At the current time we are not using robots for microsurgical training in the UK. However the Griffin Institute in London now has three Da Vinci robots and three training consoles to help train urologists. We hope to be able to offer microsurgical training with these in the future. Though these robots are now being superseded by robots specifically designed for microsurgery such as the Symani microrobot.

\section{Future in Microsurgery education; virtual}

In order to inspire microtraining I have researched the least expensive way to get a home or lab set up (with microscope) and have shared this knowledge on the web, hoping to inspire training in less well-off countries. (3. Shurey, 2020. Home or Lab Set up).

Also, during lockdown due to the Corona-19 virus I have devised 20 e-learning modules for basic microsurgery along with the unedited core videos and placed these on You tube. (4. Shurey, 2020. E-Learning Modules).

Hopefully they will inspire hospitals and labs to set up their own training spaces for their young microsurgeons and in the future, if they can obtain the equipment we can start to encourage virtual training.

\section{REFERENCES}

1. Green C.J. Microsurgery in the Clinic and Laboratory. Laboratory Animals. 1987;21:1-10

2.Shurey S. MicroShure Microsurgery Facebook Page. 2020. https://www.facebook.com/Microsurgical Training/?modal=admin_todo_tour

3. Shurey S. Home or Lab ${ }^{-}$Set up You Tube. 2020. https://www.youtube.com/channel/UCytdJXQfxRijsy JRRPailjg/videos 
4. Shurey S. E-Learning Modules You Tube. 2020. https://www.youtube.com/channel/UCytdJXQfx RijsyJRRPailjg/videos

5. Shurey S. Module 6: End to End Arterial Anastomosis You Tube. 2020. https://www.youtube.com/channel/ UCytdJXQfxRijsyJRRPailjg/videos

6. Shurey S. Module 8: End to Side Anastomosis You Tube. 2020. https://www.youtube.com/channel/ UCytdJXQfxRijsyJRRPailjg/videos

7. Shurey S. Module 4: Microsurgical Training Models You Tube. 2020. https://www.youtube.com/channel/ UCytdJXQfxRijsyJRRPailjg/videos

8. Shurey S. Module 5: Factors Affecting Anastomotic Success You Tube 2020. https://www.youtube.com/ channel/UCytdJXQfxRijsyJRRPailjg/videos

9. Ghanem A.M., Al Omran Y., Shatta B., Kim E., Myers S. Anastomosis Lapse Index (ALI): A Validated End Product Assessment Tool for Simulation Microsurgery Training. J Reconstr Microsurg. 2016 Mar;32(3):233-41.

10. Pafitanis G., Veljanoski D., Ghanem A.M., Myers S. Intimal Surface Suture Line (End-Product) Assessment of End-to-Side Microvascular Anastomosis. Plast Reconstr Surg 2017 Glob Open vol. 5, (7) e1409-e1409.

11. Shurey S. Module 10: <1mm End to End Anastomosis You Tube. 2020. https://www.youtube.com/ channel/UCytdJXQfxRijsyJRRPailjg/videos

12. Shurey S. Module 11: <1mm End to Side Anastomosis You Tube. 2020. https://www.youtube.com/ channel/UCytdJXQfxRijsyJRRPailjg/videos

13. Pafitanis G., Serrar Y., Raveendran M., Ghanem A.M., Myers S. The Chicken Thigh Adductor Profundus Free Muscle Flap: A Novel Validated Non-Living Microsurgery Simulation Training Model. Arch Plast Surg. 2017 Jul; 44(4): 293-300.

14. Shurey S. Module 11: Femoral Artery to Carotid Loop You Tube. 2020. https://www.youtube.com/channel/ UCytdJXQfxRijsyJRRPailjg/videos

15. Shurey S. Module 9a: Interpositional Vein Graft You Tube. 2020. https://www.youtube.com/channel/ UCytdJXQfxRijsyJRRPailjg/videos

16. Shurey S. Module 15: Renal Model with Continuous Suturing You Tube. 2020. https://www.youtube.com/ channel/UCytdJXQfxRijsyJRRPailjg/videos

Поступила в редакцию 25.12.2020, утверждена к печати 18.02.2021 Received 25.12.2020, accepted for publication 18.02.2021

Information about author:

Sandra Shurey, MPhil, MicroShure Microsurgery, UK based Microsurgical Tutor, Devon UK

E-mail: MicroShure@yahoo.co.uk

Сведения об авторе:

Сандра Шури, MPhil, тьютор по микрохирургии (г. Аевон, Векикобритания).

E-mail: MicroShure@yahoo.co.uk 